\title{
静止衛星上での監視にもとづくニアミス回避について*1 Geostationary Satellite Near-Miss Avoidance Using On-Board Monitoring
}

\author{
川 瀬 成 一 郎*2 \\ Sei-ichiro KAWASE
}

Key Words : Geosynchronous Satellite, On-Board Angle Tracking, Orbit Determination

\begin{abstract}
In this paper we discuss the use of a monitoring camera on board a satellite to detect unknown satellites coming so close as to cause collision risk. We assume that a camera on board our satellite tracks direction angles of an unknown target satellite and try simulations of determining the target's trajectory relative to our satellite. Simulations show that we cannot determine uniquely the target's trajectory, while showing that we can decide whether we need a collision avoidance maneuver and can determine its strategy when we need it. The on-board camera does not need precise alignment, as the bias in direction angles can be estimated as an unknown parameter. On-board monitoring can thus be practical for orbital risk avoidance.
\end{abstract}

\section{1. は じめに}

衛星通信の世界的な普及にともない, 新しい通信衛星が 次々と静止軌道に投入されて, 軌道が混杂隹するようになっ た . 静止軌道の利用に関しては取り決めか設けられていて， どの衛星も軌道上で存在してよい経度の範囲を固有に割り 当てられ，乥こから出ないように保つ.これにより軌道の 利用には秩序が保たれてきた．しかしながら軌道の混雑が すすんでいけば，衛星どうしが接近しすぎることへの懸念 が生じる ${ }^{1)}$. 第 1 図は关れに類する事例のひとつを示すも ので, 静止衛星の軌道位置を測定する電波干渉計 2 をを試験 していたところ，2 衛星の経度が重なるように動くのが見 られた .こういう事例が起きる背景としては, 同じ経度範 囲に複数の衛星が割り当てられていて, 衛星は互いに間隔 を保つように協調して管制するはずであったがうまく協調 できていないか，もしくは衝突の危険は少ないと見なして 協調なしに管制している，という状況が考えられる．ある いは別の経度にあった衛星が, 何らかの事情でドリフトし て来たという状況も考えられる．2 衛星の経度が重なりあつ ても，緯度や半径に間隔があれば衝突には至らないから， 必ずしも第 1 図のような事例がただちに重大な危険を招く とはいえない．しかし何らかの危険があることは疑いなく， 产のような危険は今後, 軌道の混雑が進むにつれて増して いくと考えなければならない.

いま, 我々の衛星の近くに未知の衛星があって, 兰れか接 近してくる懸念があるという場面を考えよう．接近の危険 度を知るためには未知衛星の軌道情報を収集する必要があ

\footnotetext{
*1 (C) 2010 日本航空宇宙学会

平成 21 年 4 月 7 日原稿受付

$* 2$ 情報通信研究機構
}

るが , 未知な衛星に対する追跡はパッシブでなければなら ない . パッシブな追跡として光学観測が考えられるが, 地 上で行う光学観測は夜間の晴天時のみという制約があるか ら，色険に備えて常時おこなうべき監視には必ずしも適さ ない，乥こで, 光学観測用の機器を我々の衛星上に設けて 監視を行うことが考えられる.このように衛星上でおこな う監視について，本報告では検討することとした .

衛星上に設けた光学観測機器についてはすでに実例があ る. 弚のひとつは高度 $900 \mathrm{~km}$ の軌道にある衛星上に設けた もので , 約 $40000 \mathrm{~km}$ の遠方にある静止衛星をターゲット とするために口径 $15 \mathrm{~cm}$ ，長さ $45 \mathrm{~cm}$ の望遠鏡を主体とし， 視野は 1.4 度 $\times 6.6$ 度とされた ${ }^{3)}$. ほかに例として展開監視 カメラというものがあり, 光れは軌道上で通信衛星等が大 型のアンテナや太陽電池パネルを展開するさいに展開の動 作を衛星上にて確認するものである .一例として，カメラ 一式を最大辺長 $18 \mathrm{~cm}$ のサイズに収めながら, 全周 360 度 $\times$ 垂直 50 度という広視野を実現したものか報告されてい る4). 我々が考えている監視では視野が広いことが望まし く，もし第 1 図に即していうならターゲットは約 $100 \mathrm{~km} の$ 距離から至近距離までの範囲にある .よって上記の実例の なかでは, 展開監視カメラのほうか我々の目的に近い，も しも, 衛星上での展開監視が終わった後，おなじカメラを 今度は周囲の未知衛星の監視に使えるように設計できたと すれば，監視カメラを無䭾なく利用できることになる．本 報告では，このようにして衛星上に設けた監視カメラを用 いることを想定した .

以下の本論では , 衛星上の監視カメラを用いて未知衛星 の軌跡を推定することの可能性を検討する . 推定の精度を 調へ， 弚れが衝突の予測と回避に役立つかどうかを検討す る.検討は軌跡推定のシミュレーションにもとづいておこ 


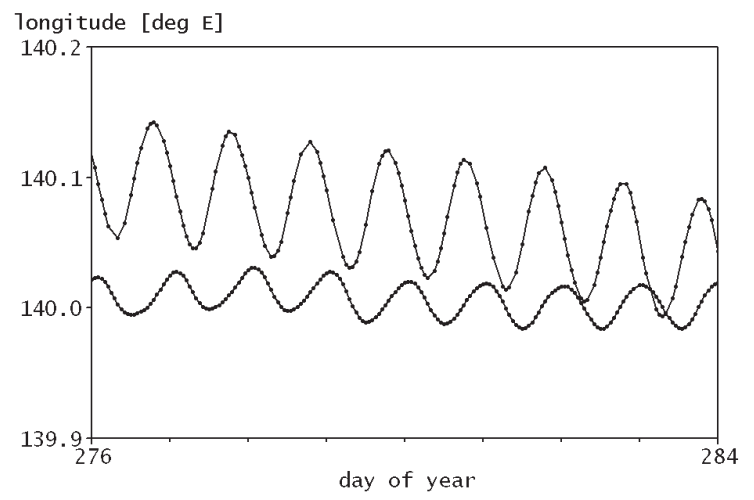

第 1 図＼cjkstart静止衛星の経度接近事例

なうもので, 以下，シミュレーションの方法と手順，およ び結果の解釈について述べる。

\section{2. 運動と 観測のモデル}

第 2 図において, 我々の衛星は $\mathrm{O}$ にあり，兴の近くに未 知の衛星 $\mathrm{U}$ があるとする . 原点を $\mathrm{O}$ とする座標軸 $L, R$, $Z$ を用いて $\mathrm{U}$ の位置を表す.$L$ 軸は $\mathrm{O}$ 点における静止軌 道の接線に， $R$ 軸は地球中心から $\mathrm{O}$ に至る半径に， $Z$ 軸 は北方向に光れ沿う。

衛星 $\mathrm{O}$ に設けた監視カメラは，Uの方向角度を観測す る. 兴のモデルとしてここでは, O から見たU の方向を角 度 $a, e$ で表す.角度 $a$ は, $Z-L$ 面からの U の離角を $Z$ 軸まわりに計り, 角度 $e$ は, $L-R$ 面からの $\mathrm{U}$ の離角を $R$ 軸まわりに計る、理論上は, カメラがとらえた衛星像の大 きさや明るさにもとづいて, 距離 OU を割り出すことも考 えられよう. しかし実際に兴れが可能になるのは未知衛星 が十分に近づいたときだから，弚れまで待つのは危険を事 前に知るための監視という主旨に乥むく.よってここでは 方向角度の観測だけを考える．

観測値 $a, e$ の精度を決める要因としては, 観測機器に固 有の精度と, 衛星の姿勢の精度とが考えられる . 通信衛星 の姿勢精度が近い将来に大きく変わることは考えにくいが， 撮像デバイスの技術進展は速いことを考えると，観測精度 を制限するのは衛星の姿勢精度であろう．通信衛星の姿勢 精度は一般に, ピッチ・ロール軸とヨー軸とで異なり，後 者のほうが誤差が大きく, 標準的な例では 0.7 度とされて いる5 ．ただし弚れは姿勢を一定に保持する制御の誤差で あって, 姿勢決定の誤差は光れに比べてファクタないし 1 オーダ小さい場合があろう．姿勢の誤差にともなって方向 観測に誤差が生じたとき，乥れは姿勢決定を参照すれば補 正できるから，観測誤差は姿勢決定誤差に相当する．こニ では, シミュレーションのためのひとつの仮定として , 方 向角度の観測誤差レベルを 0.2 度とおく . 監視カメラの視 野は, 通信衛星に乥なわる大型のアンテナや太陽電池パネ ルによって妨げられる可能性がある . 妨げられる度合いは 衛星によって異なり得るので, 一般的なモデルは立てられ ない．ここでは検討の第一歩として，視野の妨げは考慮に 入れないものとする .

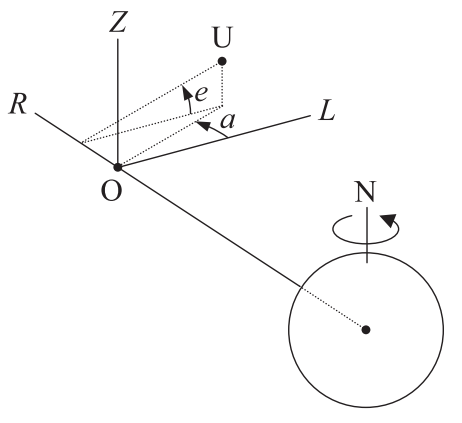

第 2 図 2 衛星の位置関係 $\mathrm{N}$ は地球の北極 .

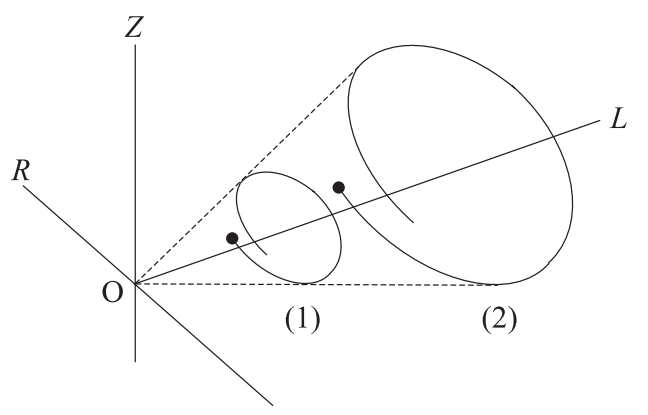

第 3 図 軌跡の拡大縮小関係

衛星 O と U が互いに近い位置にあって，しかも両衛星 とも軌道制御をしないとすると，Uの運動は線形近似にも とづく次の方程式に従う ${ }^{6)}$.

$$
\left.\begin{array}{l}
R^{\prime \prime}+2 L^{\prime}-3 R=0 \\
L^{\prime \prime}+2 R^{\prime}=0 \\
Z^{\prime \prime}+Z=0
\end{array}\right\}
$$

ここで ()$^{\prime}$ は $\mathrm{d}(\mathrm{)} / \mathrm{d} s$ を表し,$s$ は時間の経過を地球の自 転角度 (ラジアン) によって計る.方程式 (1)のひとつの解 を $L(s), R(s), Z(s)$ とすると，これに任意の係数 $k$ を掛 けた $k L(s), k R(s), k Z(s)$ も，おなじく方程式の解になる 解が表す軌跡を図形として第 3 図に描き，ひとつの軌跡 (1) に係数を掛けて拡大した軌跡を (2) とする.軌跡 (1) と軌 跡 (2) は，O を中心として互いに拡大縮小した関係にある 衛星 U か軌跡 (1) にある場合と, 軌跡 (2) にある場合を比 べると，Oから Uを見る方向角度に違いはない．よって方 向角度をどれだけ観測しても，(1) と (2)のように拡大縮小 の関係にある軌跡を見分けることができない．

ではU の軌跡推定はまったく不可能かというと, 必ずし も光うではない，いま，UはＯ衝突する軌跡にあるとし よう．乥の軌跡を例えば $L-R$ 面に投影したものを，第 4 図 のA において (1) とする . 弚れと拡大縮小関係にある $(2)$ においても，衝突という特性は変わらない，次にUは，第 4 图のB において非衝突の軌跡 (1) にあったとすると , (1) と拡大縮小関係にある軌跡 $(2)$ においても, 非衝突という 特性は変わらない.よって理論上は, 方向角度の観測にも とづいて衝突の発生の有無を判断できるはずである. 実際 上は，Uが $\mathrm{O}$ に最も接近したときに，どういう精度で位置 

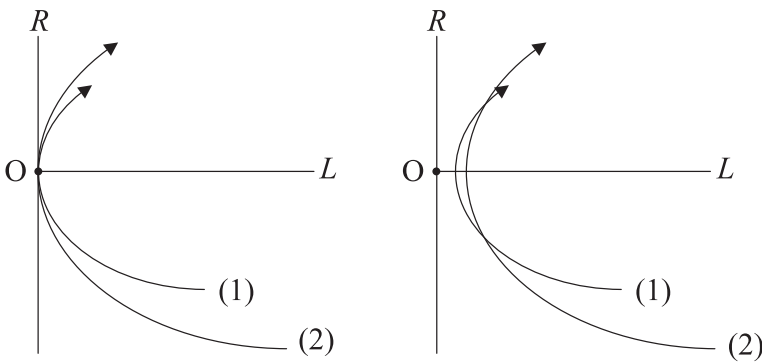

A: Colliding

B: Non-colliding

第 4 図衝突軌跡と非衝突軌跡

を推定できるかが問題になる，乥れを調べるために，推定 の方法を具体的に定め, 衛星 Uが進入してくる軌跡を想定 して , 推定のシミュレーションを以下のようにおこなう.

\section{3. 軌跡推定の方法}

衝突の危険を予測するという目的から，軌跡の推定はリ アルタイムにおこなうのがよい .ここでは方向角度の観測 からカルマンフィルタによって未知衛星の軌跡を推定する ことを考える. 乥してフィルタに現れる状態共分散行列を みることで，推定精度を調べることにする．

推定すべき状態べクトルを次のようにおく .

$$
\boldsymbol{x}=\left(L, R, Z, L^{\prime}, R^{\prime}, Z^{\prime}, A, E, S\right)^{\mathrm{T}}
$$

ここで $A, E$ は，観測された角度 $a, e$ に光れ光れ含まれ得 るバイアス値を表す.$S$ は衛星に働く太陽輻射圧力の効果 を表すパラメータで，2 衛星について差分的に表している. すなわち衛星 $\mathrm{O}$ に働く太陽輻射圧力を基準として , 相対的 にUに働く太陽輻射圧力を $S$ によって表す．このような 差分的な表現は, 運動方程式 (1) が線形であることから許 される .このほかに静止衛星に㗢く捸動としては月・太陽 の引力 , 地球のポテンシャルがあるが , これらについては, 近接する 2 衛星に働く力は共通であるから 2 衛星の相対的 な運動に影響を与えないと見なして，ここでは考慮に入れ ない.

状態ベクトル $\boldsymbol{x}$ が，時刻 $s_{1}$ における $\boldsymbol{x}_{1}$ から，時刻 $s_{2}$ における $x_{2}$ に遷移する法則を次のように記す．

$$
\boldsymbol{x}_{2}=\Phi\left(s_{2}, s_{1}\right) \boldsymbol{x}_{1}
$$

ここで $\Phi$ は $9 \times 9$ の遷移行列で, 次のように構成される .

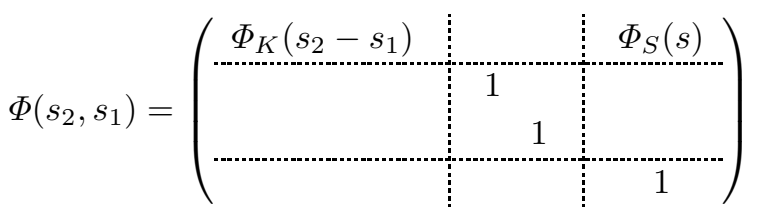

ただし行列内の空白か所は零を表す. 部分行列 $\Phi_{K}$ は 2 体 問題による軌道運動を表すもので, 方程式 (1) から次のよ うに導かれる6).

$$
\Phi_{K}(s)=\left(\begin{array}{cccccc}
1 & 6 s-6 \sin s & 0 & 4 \sin s-3 s & 2-2 \cos s & 0 \\
0 & 4-3 \cos s & 0 & 2 \cos s-2 & \sin s & 0 \\
0 & 0 & \cos s & 0 & 0 & \sin s \\
0 & 6-6 \cos s & 0 & 4 \cos s-3 & 2 \sin s & 0 \\
0 & 3 \sin s & 0 & -2 \sin s & \cos s & 0 \\
0 & 0 & -\sin s & 0 & 0 & \cos s
\end{array}\right)
$$

部分行列 $\Phi_{S}$ は, 太陽輻射圧力の効果を表すもので , 次の ように設定する.太陽は $L-R$ 面上にあって , 兴の方向はシ ミュレーションのあいだ変わらないものと仮定する . 時間 $s$ の経過につれて,$L-R$ 座標系は慣性空間のなかで回転す るから， $L-R$ 面上で太陽が見える方向は逆むきに回転し， 弚れを単位べクトルで書けば $(\cos (-s), \sin (-s))$ のように なる．よって太陽光が衛星 U を押す力は, $-\cos s, \sin s$ に 弚れ光れ比例する $L, R$ 成分をもつ. 時刻 $s_{1}$ から時刻 $s_{2}$ への刻み幅は小さいとすると, 炎の間に太陽光に押される ことによって速度の $L, R$ 成分に光れ艺れ $-\cos s, \sin s に$ 比例した増分が生じる . 対応して状態べクトルには

$$
\Delta \boldsymbol{x}=\left(\begin{array}{lllllllll}
0 & 0 & 0 & -S \cos s & S \sin s & 0 & 0 & 0 & 0
\end{array}\right)^{\mathrm{T}}
$$

という増分が加算されることになる (ただし $s$ は $s_{1}$ と $s_{2}$ の中点にとる) . 係数 $S$ (速度増分の大きさを表している が, 時刻の刻み幅を一定にとるものとすれば, $S$ も一定と おいてよい.㫕こで $(2)$ 式において

$$
\Phi_{S}=\left(\begin{array}{llllll}
0 & 0 & 0 & -\cos s & \sin s & 0
\end{array}\right)^{\mathrm{T}}
$$

とおけば，(4) 式による加算分を考慮に入れたことになる 状態ベクトル中のパラメータ $A, E, S$ はどれも, シミュ レーションの期間を通じて変わらないはずだから, 遷移行 列 $(2)$ において $(7,7)$ 要素,$(8,8)$ 要素,$(9,9)$ 要素を 1 とおく.

方向角度の観測モデルは

$$
\begin{aligned}
& a=\tan ^{-1} R / L+A \\
& e=\tan ^{-1} Z / L+E
\end{aligned}
$$

と書かれ, 対応して観測行列は次のように算出される．

$$
\begin{aligned}
H & =\left(\begin{array}{c}
\partial a / \partial \boldsymbol{x} \\
\partial e / \partial \boldsymbol{x}
\end{array}\right) \\
& =\left(\begin{array}{cccccccccc}
\frac{-R}{L^{2}+R^{2}} & \frac{L}{L^{2}+R^{2}} & 0 & 0 & 0 & 0 & 1 & 0 & 0 \\
\frac{-Z}{L^{2}+Z^{2}} & 0 & \frac{L}{L^{2}+Z^{2}} & 0 & 0 & 0 & 0 & 1 & 0
\end{array}\right)
\end{aligned}
$$

以上に定めた状態遷移行列，観測モデル，観測行列を用 いて, 観測值 $a, e$ から状態ベクトル $\boldsymbol{x}$ を推定するフィル 夕を構成する.

\section{4. 推定のシミュレーション}

衛星 Uが $\mathrm{O}$ に向かって進入してきて衝突に至る軌跡を， 一例として第 5 図のように想定する .これは第 1 図の例に 

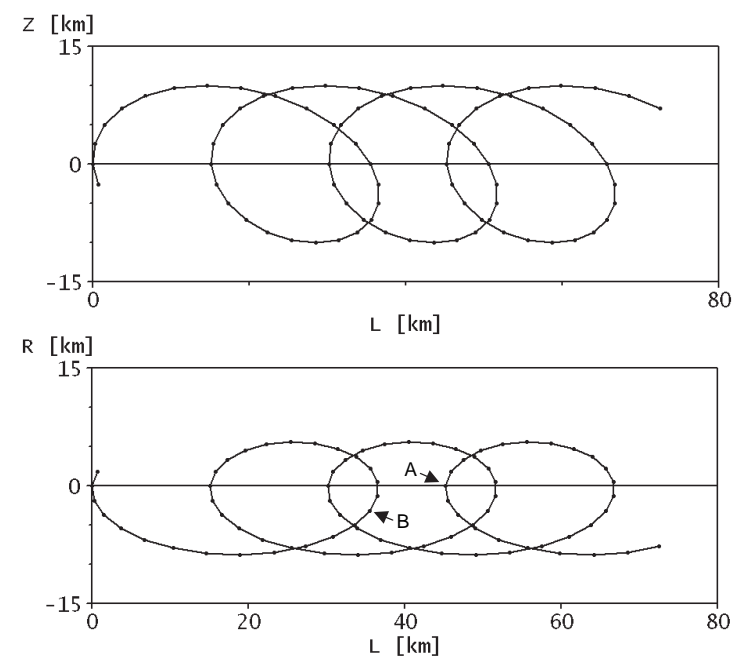

第 5 図 進入軌跡の一例

見られたように, 経度が周期的に変化しながら接近してく る場合に相当し，あわせて南北にも周期変化をともなうよ うな軌跡を運動法則 (3) を用いて生成した .この軌跡にも とづいて観測值 $a, e$ を 1 時間ごとに生成し, 推定フィルタ に入力することでシミュレーションをおこなう．観測値の 生成にさいしては，Uに働く太陽輻射圧力を零とおき，観 測值 $a, e$ のノイズとバイアスも零とした . 乥して, 推定さ れた軌跡が上記の想定軌跡に一致し，かつ推定パラメータ $A, E, S$ が零に収束することをもってフィルタの動作を確 認しながら，Uの位置の共分散誤差を評価することとした .

観測と推定のプロセスについては次のように想定する . 第 5 図において, 進入してきた衛星Uを見つけた後, 弚れ が A 点を通過したときに観測を開始して推定フィルタを起 動する . 弚の後, 観測を 1 時間ごとにおこなうたびに軌跡 をリアルタイムに推定していくが，Uが $\mathrm{O}$ に至る時刻から 12 時間前の時点（第 5 图では B 点）に来たときに，弚れ から先の軌跡を一括して予測する．つまり，最接近より 12 時間前の時点において衝突の可能性を見きわめ, 回避行動 の要否を判断するものと想定した .

フィルタを起動するさいには状態べクトル $\boldsymbol{x}$ に初期値を 与えなければならないが, 未知衛星 U の位置や速度につ いて事前の情報はない，乥こで初期位置としては，仮説的 にUが $L$ 軸上の $20 \mathrm{~km}, 40 \mathrm{~km}, 60 \mathrm{~km}$ の各点にある場合 を想定し，初期速度は零とおく．これらに光れ光れ対応す る初期ベクトルを作り，3 とおりのフィルタリングを実行 する.パラメータ $A, E, S$ の初期值には光れ光れ $1 \mathrm{deg}$ ， $1 \mathrm{deg}, 0.01 \mathrm{~m}^{2} / \mathrm{kg}$ を与えた . フィルタの起動のさいには， あわせて状態共分散行列にも初期值を与える必要があるが， 事前の情報はないことを表すために行列の対角要素に大き い值を与える . 具体的には位置の 3 成分に $(1000 \mathrm{~km})^{2}$ を， 速度の 3 成分に $(1000 \mathrm{~km} / \text { day })^{2}$ を与えた . 観測量 $a, e$ の誤差共分散行列に関しては， 2 節での考察にもとづいて， $(0.2 \mathrm{deg})^{2}$ を対角要素に与えた .

以上の諸条件によるシミュレーションの結果 , 推定され
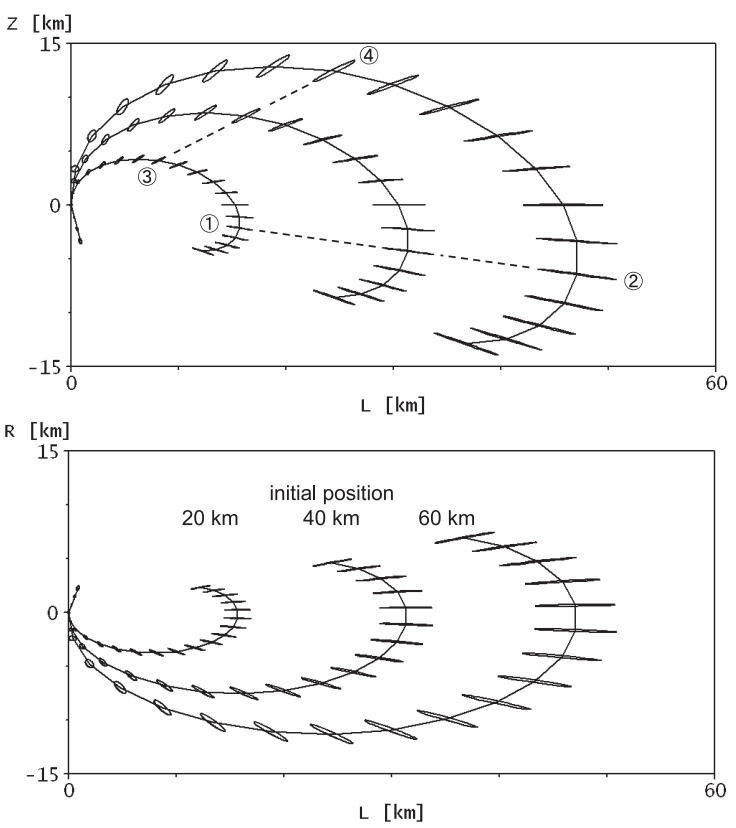

第 6 図 推定軌跡と誤差楕円

た軌跡を第 6 图に示す . 推定軌跡は $\mathrm{O}$ に衝突することを再 現していて, しかもパラメータ $A, E, S$ はどれも 0.001 以 内に収束したことからフィルタの動作は正しいと確認した . 図示の軌跡は衝突の 18 時間前より以降について表示した もので, 軌跡の上には位置の誤差範囲を表す楕円を重ねて 描いてある . 誤差楕円は状態共分散行列の位置成分要素に もとづいて描いたもので，Uの位置が $95 \%$ の確率で存在す る範囲を表す。

パラメータ $A, E$ が正しく収束したことから，角度観測 のバイアスを推定できることがわかったが，このことは注 目に値する、衛星上に監視カメラを取り付けるさいに, 取 り付け角に誤差があれば何らかの観測バイアスを生じる． そのバイアスを推定できるのなら, カメラの取り付け精度 への要求が緩和されるので, 実際上の意味が大きい.

第 6 図に描く推定軌跡は, 前記の初期位置を $L$ 軸上の どこにとるかに対応して拡大または縮小される関係にあっ て，乥れは第 4 図の A において (1) と (2) の関係から予想 されるとおりに現れた．弚のように現れるのは必ずしも自 明ではなく, シミュレーションによって確認されたものと 見なければならない，なぜなら，状態べクトルは余分な推 定パラメータ $A, E, S$ を含み, しかも第 5 図のB 点より 以降は観測をともなわない予測となっているからである .

第 6 图に現れた誤差楕円については, 以下のように解釈 するのがよい，推定軌跡は互いに拡大縮小される関係にあ るが, 誤差楕円の形もまた同じ拡大縮小の関係に従う . 前 記で想定した初期位置は，単に仮説的においたものであつ たが, 実際には初期位置を数十 $\mathrm{km}$ きざみでラフに見積も ることが可能な場合があろう.例えば監視カメラがUを捉 えた時点で, カメラの感度にてらしておおまかな位置を割 り出すことが考えられる. 兴の結果, ここでは初期位置が $L$ 軸上の $20 \mathrm{~km}$ から $60 \mathrm{~km}$ までの区間のどこかにあると 

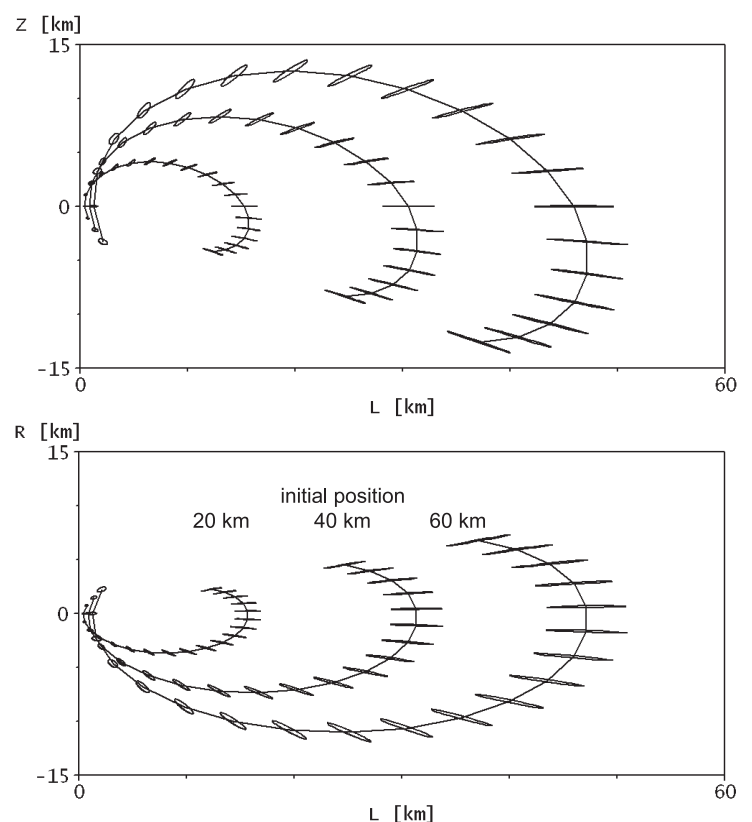

第 7 図 推定軌跡と誤差楕円

見積もられたとしよう．すると対応して第 6 図では，例え ば(1)から(2)の位置まで誤差楕円が連続的に動いて覆う細長 いエリアが，U の位置の誤差範囲を表す . これを誤差エリ アと呼ぶことにすると，時間が経過するにつれて誤差エリ アは , 例えば(3)-(4)のように縮小し， O 点にむかうにつれて さらに縮小していく. 誤差エリアがこのように縮小するこ とは，衝突の発生を判断するうえで都合がよい．

次に別のシミュレーションのために，第 5 図に示した軌 跡を修正して, 軌跡の全体を $L$ 軸の正方向に $1 \mathrm{~km}$ 移動し た .このとき $\mathrm{U}$ は $\mathrm{O}$ に対して, $1 \mathrm{~km}$ のニアミスを起こす . この軌跡を用いたシミュレーションの結果を第 7 図に示す . 推定軌跡は, 第 4 図のB において (1) と (2) の関係から予 想されるとおりに現れることか確認された .

\section{5. 回避の判断と実行}

未知衛星が存在する範囲は上記のように, 誤差楕円が動 いて覆う誤差エリアとして表されることを見た . 兴の誤差 エリアが, 最接近点の付近においてどう現れるかにもとづ いて, 衝突の危険の有無すなわち回避行動の要否を判断す ることになる．光こで第 6 図と第 7 图から，原点の付近に 現れた誤差棈円を拡大して, 第 8 图と第 9 図に描いた . 図 中のケース $\mathrm{a}$ と d (ミス距離が $0 \mathrm{~km}$ と $1 \mathrm{~km}$ ) については すでに第 6 図と第 7 図のなかに小さく現れているが , ほか にケース b と c (ミス距離が $0.2 \mathrm{~km}$ と $0.5 \mathrm{~km}$ ) を加えて ある．ミス距離を変えるにはここでも，第 5 図に示す軌跡 を $L$ 軸の正方向に移動した . 推定の結果が第 8 図 , 第 9 図 のように示されたとすると，回避の要否は以下のように判 断されるであろう.

ケース a と b では，回避を要すると判断される . 未知衛 星は $Z$ 軸方向の速度成分をもって進入してくるので，光れ を回避するには, 最接近の予定時刻における衛星 $\mathrm{O}$ の位

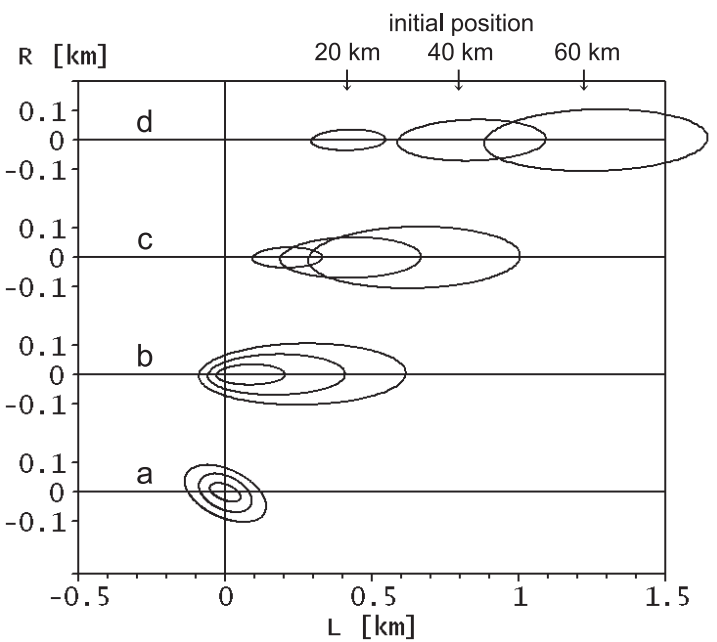

第 8 図誤差楕円の拡大図 ( $L-R$ 面) ケース $\mathrm{a}, \mathrm{b}, \mathrm{c}, \mathrm{d}$ の順に，ミス距離 $0 \mathrm{~km}$, $0.2 \mathrm{~km}, 0.5 \mathrm{~km}, 1 \mathrm{~km}$.

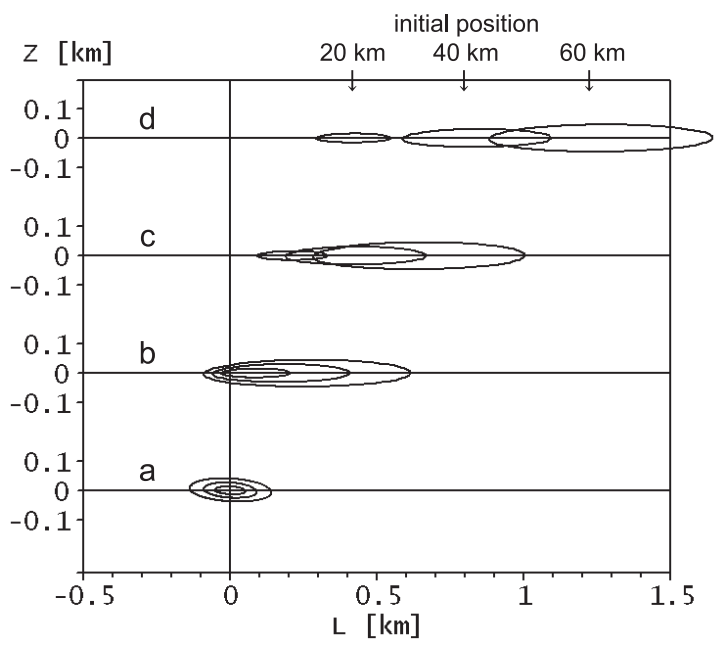

第 9 図 誤差楕円の拡大図 ( $L-Z$ 面) ケース $\mathrm{a}, \mathrm{b}, \mathrm{c}, \mathrm{d}$ の順に , ミス距離 $0 \mathrm{~km}$, $0.2 \mathrm{~km}, 0.5 \mathrm{~km}, 1 \mathrm{~km}$.

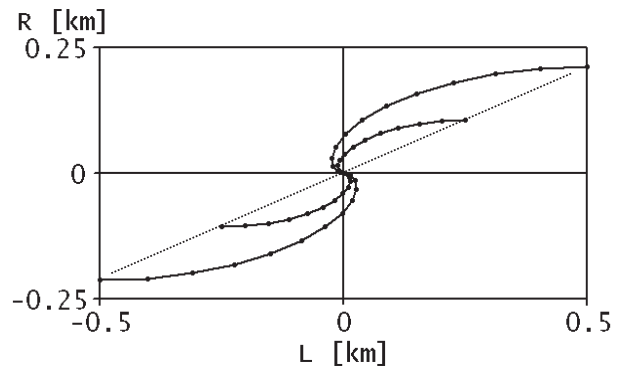

第 10 図 $L$ 方向 $\Delta v$ による 12 時間後の変位

置を， $L-R$ 面内で変位させておくのがよい．ここでは回 避用の $\Delta v$ を，最接近の 12 時間前に実行するものと想定 する．通信衛星は $\pm L$ 方向に $\Delta v$ を発生できるので，光 れを実行すると，弚の 12 時間後までのあいだに衛星位置 は運動法則 (3) に従って第 10 图のように变位する.变位 は $\Delta v$ の大きさと正負に応じて図の点線上のどこかに現れ， 
$\Delta v=4 \mathrm{~mm} / \mathrm{s}$ のとき $L$ の変位は $0.5 \mathrm{~km}$ になる . この第 10 图を第 8 図に重ねて見ると，回避のおこない方を決める ことができる.第 8 図のケース a では，例えば $0.5 \mathrm{~km} の$ 变位を $L$ 軸の正または負の側に起こすことで十分な回避 ができる.第 8 図のケース b では, 誤差エリアの広がりと 兴の不確定を考慮して, $L$ 軸の負の側へ変位させて回避す るのがよい .ケース $\mathrm{c}, \mathrm{d}$ では回避は不要と判断されるが， もし大事をとって回避をおこなうとすれば，ここでも $L$ 軸 の負の側へ変位を起こす . 大事をとる判断をくだすために は, 前記により初期位置を見積もるさいに, 弚の広がり幅 の両端のうち原点に近いほうを, より原点に近づけておけ ばよい.

もしも未知衛星の進入軌跡が $L-R$ 面内にあって，しか も光の原点付近での向きが第 10 図の点線の向きに一致す るような特別な場合には, $L$ 方向 $\Delta v$ による面内回避は難 しい. 兴の場合には軌道面外に变位を起こして回避すれば よく，弚れには最接近の 6 時間前に $Z$ 方向 $\Delta v$ を発生す る. このときは $\Delta v=3.7 \mathrm{~cm} / \mathrm{s}$ によって $0.5 \mathrm{~km}$ の変位が 起きる . 上記の特別な場合に該当するかどうかは，推定さ れた軌跡を見ることで判断するが，光の判断は，たとえ推 定された軌跡に拡大縮小がともなっていても適切におこな うことができる．

最接近時における誤差棈円の形状は, 第 8 图と第 9 図に 見るように， $L$ 軸方向に長く伸びる.この形状が，進入軌 跡の形に依存するかどうかを見るために, 第 5 図に示した 軌跡を変更し， $Z$ 成分の動きを第 11 図のように変えた . のとき未知衛星は, $Z$ 軸上の $+1 \mathrm{~km}$ の点を，ほぼ $R$ 軸に 平行に通過して $1 \mathrm{~km}$ のニアミスを起こす．このケースに ついてシミュレーションをおこなうと，最接近時の誤差楕 円は第 12 図のように現れ，ここでも誤差楕円は $L$ 軸方向

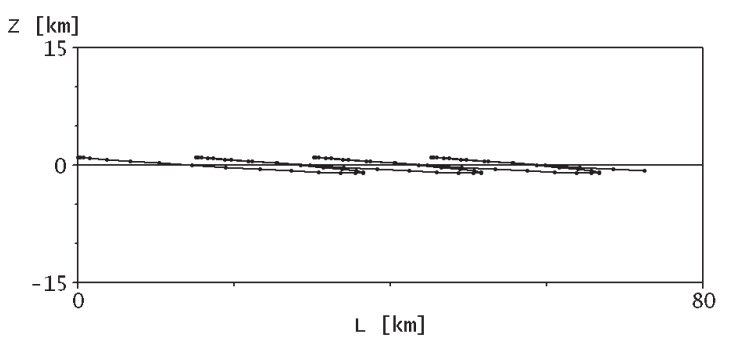

第 11 図 進入軌跡の別例

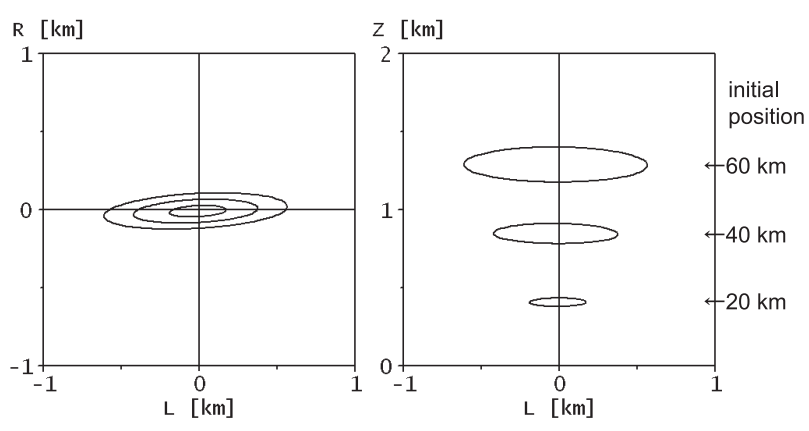

第 12 図誤差楕円の拡大図
に伸びる.(ただし誤差楕円が覆って作る誤差エリアは，こ こでは扇状の形になることに注意）誤差楕円が $L$ 軸方向 に長くなる理由は, 結局のところ $L$ 軸に沿った位置情報が ほとんどないことによると考えられる .

推定の結果が第 12 図のように示されたとすると，回避は 要しないと判断される．もし大事をとって回避をおこなう とすれば, 最接近の予定時刻における衛星 $\mathrm{O}$ の位置を $Z$ 軸 に沿って負の側入変位させておくのがよい，乥れには最接 近の予定時刻から 6 時間前に $-Z$ 方向の $\Delta v$ を発生する

以上をまとめると, 軌跡の推定には拡大縮小の不定性が 避けられないが, 誤差エリアの大きさは最接近点において 最も小さくなることに着目すれば，衝突の有無を事前に判 断することができる．乥して回避行動を要する場合には光 のストラテジーを決めることができる .

$$
\text { 6. 補足 }
$$

以上おこなったシミュレーションでは, 簡略化した点が いくつかあった . 太陽輻射圧力を考慮するさいに，太陽は赤 道面にあって弚の方向は変わらないと仮定したが, 現実は 产のとおりではない，また，太陽輻射圧力の効果を計算に 入れるさいには速度増分を (4) 式で表して加算したが，光 れは積分を台形公式で近似するものだから近似誤差をとも なう.しかしながら，ここでの目的は状態共分散行列に着 目して誤差を見積もることにあり，弚のための要件は状態 ベクトルのなかにパラメータ $S$ を存在させることにある 乥してフィルタの動作につれてパラメータ $S$ か零に収束す れば，上記の積分の近似誤差は影響をもたなくなる．よっ て，誤差見積もりを目的としたシミュレーションは適切に おこなわれたと考えてよい.

別の簡略化として, 衛星 U と衛星 O の運動を相対的な運 動としてとらえ，乥れを線形近似による方程式 (1) で表し た . 谷の近似にともなう誤差は, 2 衛星の間隔が小さいほ ど，つまり衝突に近いときほど小さくなる．したがって光 の近似誤差が，衝突回避に関する検討におよぼした影響は 少ないと考えてよい，ただし，拡大縮小関係の広域的な現 れ方については影響をおよぼした可能性があり，乥れを明 らかにするには, 軌道運動のモデルを衛星個別に設けた厳 密なシミュレーションを要する. 弚して厳密シミュレーショ ンの結果を解棌するにおいては再び，誤差楕円と誤差エリ アという本報告で示した観点に立ちもどることになろう .

$$
\text { 7. ま と め }
$$

静止衛星上での方向観測にもとづいて, 未知の衛星が接 近してくる軌跡を推定することの可能性を調べた . 観測を 数日間にわたって続けるあいだ末知衛星は軌道制御をしな いなら，衝突の発生の有無を事前に判断できることを示し た .さらに, 衝突を回避するストラテジーを決められるこ とも示した . 衛星上での展開確認用に設ける監視カメラを 利用して，周囲の未知衛星を監視することがもしも可能で あれば，高いコストをかけることなく安全監視の手段を得 られることになる．監視カメラの視野の確保および衛星の 
姿勢決定にもとづく方向観測精度の確保については, 厳密 なシミュレーションによる確認とあわせてさらに検討を要 するが，光の検討をすすめる価值があることを本報告は示 したといえよう .

\section{参 考 文 献}

1) Chobotov, V. A. and Johnson, C. G.: Effects of Satellite Bunching on the Probability of Collision in Geosynchronous Orbit, J. Spacecraft Rockets, 31 (1994), pp. 895-899.

2）川瀬成一郎，澤田史武 : 可動基線電波干渉計による静止軌道の監
視，電子情報通信学会論文誌 B , 84 (2001), pp. 1000-1009.

3) Lambour, R., Bergemann, R., von Braun, C. and Gaposchkin, E. M.: Space-Based Visible Space Object Photometry: Initial Results, J. Guid. Control Dynam., 23 (2000), pp. 159-164.

4) 竹家章仁, 山田克彦, 松岡 忍, 伊地智幸一, 中村修治 : 衛星 搭載全方位モニタカメラの開発，日本航空宇宙学会論文集，55 (2007), pp. 497-502.

5) Agrawal, B.: Design of Geosynchronous Spacecraft, PrenticeHall, Englewood Cliffs, 1986, p. 161.

6) Prussing, J. E. and Conway, B. A.: Orbital Mechanics, Oxford University Press, New York, 1993, pp. 139-154. 